$\begin{array}{ll}\text { Research Square } & \begin{array}{l}\text { Preprints are preliminary reports that have not undergone peer review. } \\ \text { They should not be considered conclusive, used to inform clinical practice, } \\ \text { or referenced by the media as validated information. }\end{array}\end{array}$

\title{
Diagnostic value of bronchoalveolar lavage-fluid soluble triggering receptor expressed on myeloid cells-1 (sTREM-1) concentration for neonatal ventilator- associated pneumonia
}

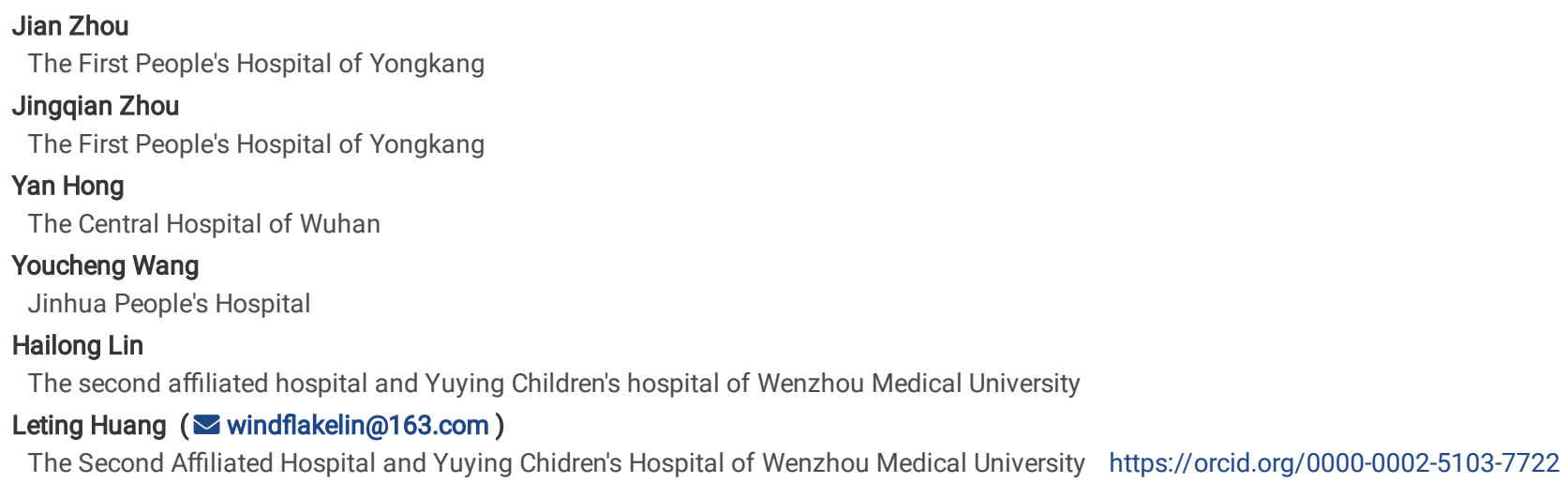

Keywords: Triggering receptor expressed on myeloid cells-1, Ventilator, Pneumonia, Ventilator-associated pneumonia, Newborn, Bronchoalveolar lavage fluid

Posted Date: October 30th, 2020

DOI: https://doi.org/10.21203/rs.3.rs-96794/v1

License: (c) (1) This work is licensed under a Creative Commons Attribution 4.0 International License. Read Full License 


\section{Abstract}

Background: Soluble triggering receptor expressed on myeloid cells-1 (sTREM-1) has regarded as a biological marker of infection.

We aimed to evaluate the diagnostic value of bronchoalveolar lavage (BAL)-sTREM-1 concentration in neonatal ventilator-associated pneumonia (NVAP).

Methods: In this multicenter, controlled clinical trial of 60 preterm and 33 full-term neonates on mechanical ventilators, we measured concentrations of BALfluid and serum sTREM-1, serum C-reactive protein, and serum procalcitonin, as well as white blood cell count. We initially divided cases into eight groups, based on three categories: preterm of full-term; NVAP or non-NVAP; and extrapulmonary infection present or absent. Groups were compared, and logistic regression analysis and receiver operating characteristic (ROC) analysis was performed to determine diagnostic value.

Results: The mean gestational age ( \pm standard deviation) of preterm and full-term neonates was $28.9 \pm 2.2$ weeks and $39.5 \pm 1.7$ weeks, respectively, and $32 / 60$ were male. The BAL-fluid STREM-1 concentration was higher in NVAP cases than in non-NVAP cases, irrespective of extrapulmonary infection. ROC analysis revealed that BAL-fluid sTREM-1 concentration had an area under the curve (AUC) of 0.986 and a cutoff value of $228.0 \mathrm{pg} / \mathrm{ml}$ (sensitivity, $94.3 \%$; specificity, $96 \%$ ) in preterm neonates; the same values in full-term neonates were 0.938 and $245.5 \mathrm{pg} / \mathrm{ml}$ (sensitivity, $100 \%$; specificity, $93.7 \%$ ), respectively. The optimal combination of indicators was BAL-fluid STREM-1 and serum C-reactive protein concentration. All indicators were present at lower levels on days 8 and 10 of ventilation in neonates who ultimately recovered than in those who did not.

Conclusions: BAL-fluid sTREM-1 and serum C-reactive protein concentrations may be useful for the diagnosis of NVAP.

\section{Blinded manuscript text}

The RCT was approved by the Ethics Review Committee ofThe First People's Hospital of Yongkang (number: ykyy201803). Furthermore, the study was registered in and approved by the Registration Centre of Clinical Trials in China (approval number: ChiCTR1900020564). URL of trial registry record:http://www.chictr.org.cn/showproj.aspx?proj=22336 Date of registration:2017-10-19

\section{Background}

Neonatal ventilator-associated pneumonia (NVAP) is a type of lung infection that occurs in newborns who are on mechanical ventilators. As such, it typically affects critically ill newborns in neonatal intensive care units. NVAP is a major source of increased length of hospitalization, illness, and death, with a mortality rate of $20-30 \%$ [1-3]. The diagnosis of NVAP is difficult and not yet standardized. A common method for diagnostic confirmation of ventilator-associated pneumonia (VAP) is sampling of lung tissue for culture, although its clinical applicability is limited, especially in infants [4]. Furthermore, the Centers for Disease Control (CDC) criteria refer to infants younger than 1 year, with no criteria specific for newborns [5]. Biological markers of infection, such as soluble triggering receptor expressed on myeloid cells-1 (sTREM-1), may improve the accuracy of the diagnosis of VAP [6, 7]. However, we are not aware of reports on its use in newborns. Therefore, in this study, our aim was to determine the diagnostic value of bronchoalveolar lavage (BAL)-fluid sTREM-1 concentration in NVAP.

\section{Methods}

\subsection{Trial design and ethics statement}

This was an open, controlled clinical trial, approved by The First People's Hospital of Yongkang's institutional ethics committee (approval number: ykyy201803). After obtaining ethics approval, we registered the trial in the Chinese Clinical Trial Registry (approval number: ChiCTR1900020564), and recruited the first participants in January 2019.

\subsection{Participants}

Case inclusion criteria were as follows: (1) newborns, including preterm and full-term; and (2) mechanical ventilation initiated within 48 hours of birth. Case exclusion criteria were as follows: (1) >28 days after birth; (2) infectious lung disease before mechanical ventilation, including neonatal pneumonia, meconium aspiration syndrome, or either local or systemic infection affecting the lungs; (3) mechanical ventilation initiated after 48 hours; (4) multiple organ failure; or (5) any other reason we deemed a subject not suitable to participate in the trial. Predetermined withdrawal criteria were as follows: (1) not meeting the inclusion criteria at any time during the trial; (2) total time of mechanical ventilation less than, or equal to, seven days; or (3) any other reason, medical or otherwise, for which we deemed it in the subject's best interest to be withdrawn from the trial. We enrolled 120 subjects in three hospitals: 51 in The First People's Hospital of Yongkang, 37 in Jinhua People's Hospital, and 32 in The Central Hospital of Wuhan. We divided these subjects into eight groups, based on three categories: preterm (pt) or full-term (ft); NVAP (P+) or non-NVAP (P-); and extrapulmonary infection present ( $E+$ ) or absent (E-). Thus, the eight groups were: ptP+E-, ptP+E+, ptP-E-, ptP-E+, ftP+E-, ftP+E+, ftP-E-, and ftP-E+. See Fig. 1 for a flow diagram of subjects enrolled and completing the trial for each of the groups.

We assessed NVAP according to criteria in the CDC's 2016 device-associated module on pneumonia events [8]: (1) temperature $>38^{\circ} \mathrm{C}$ or $<36^{\circ} \mathrm{C}$; $(2)$ white blood cell count $>12,000 / \mathrm{mm}^{3}$ or $<4,000 / \mathrm{mm}^{3}$; (3) purulent/increased/change in character of respiratory secretions; (4) positive tracheal/bronchoalveolar lavage cultures; (5) signs of respiratory distress, such as shortness of breath, rapid breathing, or abnormal breathing sounds upon auscultation; (6) increased oxygen requirement/ventilator demand; (7) at least two serial chest X-rays revealing sustained/worsening shadowing (infiltrates/consolidations); and (8) positive cultures obtained directly from lung tissues. The criteria used for diagnosis of VAP vary by institution, especially in terms of neonates, although it 
tends to be a combination of radiographic, clinical, and laboratory evidence. In this study, we diagnosed a patient with NVAP based on criterion (7) and at least three of criteria (1)-(6); we also diagnosed a patient with NVAP based on criterion (8).

\subsection{Interventions}

We measured six indicators every two days from the $4^{\text {th }}$ to the $10^{\text {th }}$ day on the ventilator: (1) white blood cell count; (2) serum C-reactive protein concentration; (3) serum procalcitonin concentration; (4) serum sTREM-1 concentration; (5) BAL-fluid STREM-1 concentration; and (6) bacterial culture of the serum and/or BAL fluid.

Three other indicators were recorded as a routine measure: (1) daily vital signs, including body temperature, respiration, pulse, and oxygen saturation; (2) daily ventilator parameters, including fraction of inspired oxygen, positive end-expiratory pressure, and/or peak inspiratory pressure; (3) chest X-rays taken on the first day of the trial, when pneumonia was confirmed, and reviewed every three days. All the patients who suffered an infection received antibiotic treatment.

BAL-fluid samples were collected according to a standard procedure [9]. Briefly, the neonate was placed supine with the head turned to the right, to predominantly sample the right lung. We instilled $1 \mathrm{ml} / \mathrm{kg}$ of $0.9 \% \mathrm{NaCl}$ into the endotracheal tube. After two ventilator cycles, the suction catheter was gently inserted $0.5 \mathrm{~cm}$ beyond the tip of the ventilator tube, and the airway fluid was aspirated into a sterile specimen trap (BALF Trap; Vygon SA, Écouen, France) with $50 \mathrm{mmHg}$ of negative pressure. This procedure was repeated with the head turned to the left, to predominantly sample the left lung. The suction catheter was rinsed with $2 \mathrm{ml}$ of saline solution. After collection, BAL-fluid specimens were homogenized and centrifuged at $1000 \times \mathrm{g}$ for $5 \mathrm{minutes}$. Cell-free supernatants were removed and the $\mathrm{pH}$ was measured using a potentiometric micromethod analyzer (ABL 725 Plus; Radiometer Medical ApS, Copenhagen, Denmark). The remaining supernatant volume was immediately frozen at $-70^{\circ} \mathrm{C}$ for later testing.

sTREM-1 was detected by sandwich enzyme-linked immunosorbent assay (Human TREM-1 Quantikine ELISA Kit; R\&D Systems, Inc., Minneapolis, MN, USA).

\subsection{Statistical analysis}

Data processing and statistical analysis was performed using SPSS Statistics for Windows, Version 17.0 (SPSS Inc., Chicago, IL, USA). Groups were compared by means of two-tailed t tests; repeated measures ANOVA and ROC (receiver operating characteristic) analysis were performed specifically for groups $\mathrm{ptP}+\mathrm{E}-$ and $\mathrm{ftP}+\mathrm{E}-$. We constructed multivariate logistic regression models incorporating different pairs of markers, and univariate logistic regression models were used when assessing one marker at a time. Continuous data were displayed as the mean \pm standard deviation.

\section{Results}

\subsection{Patient demographicsand pathogens}

We analyzed 60 preterm and 33 full-term neonates, none of which tested positive for both pneumonia and extrapulmonary infections; thus analysis was conducted only on six groups. See Fig. 1 for numbers enrolled in, and excluded from, each group. The majority of preterm neonates (32/60) analyzed were male. The mean gestational age of preterm and full-term neonates was $28.9 \pm 2.2$ weeks and $39.5 \pm 1.7$ weeks, respectively.

The diseases identified in preterm neonates included neonatal respiratory distress syndrome, necrotizing enterocolitis, neonatal hyperbilirubinemia, neonatal cerebral ischemia, and neonatal septicemia. The diseases identified in full-term neonates included neonatal hypoxic ischemic encephalopathy, neonatal hyperbilirubinemia, congenital lactic acidosis, neonatal septicemia, and congenital megacolon.

\subsection{Indicators}

In terms of day 4 BAL-fluid sTREM-1 levels (Fig. 2a), there was a difference between the ptP+E- $(508.25 \pm 180.70 \mathrm{pg} / \mathrm{ml}) \mathrm{and} \mathrm{ptP-E-}(115.50 \pm 49.01 \mathrm{pg} / \mathrm{ml})$ groups $(t=9.0135, \mathrm{P}<0.05)$, as well as between the ptP+E- and ptP-E+ $(140.89 \pm 53.19 \mathrm{pg} / \mathrm{ml})$ groups $(t=5.2855$, $\mathrm{P}<0.05)$, but not between the ptP-E- and ptP$\mathrm{E}+$ groups $(t=1.1370, \mathrm{P}>0.05)$. There was a difference between the $\mathrm{ftP}+\mathrm{E}-(742.57 \pm 207.76 \mathrm{pg} / \mathrm{ml})$ and ftP-E- $(106.00 \pm 33.01 \mathrm{pg} / \mathrm{ml}) \mathrm{groups}(t=12.3704, \mathrm{P}$ $<0.05)$, as well as between the ftP+E- and ftP-E $(138.64 \pm 40.86 \mathrm{pg} / \mathrm{ml})$ groups $(t=6.9711, \mathrm{P}<0.01)$, but not between the ftP-E- and ftP-E+ groups $(t=1.7552, \mathrm{P}$ $>0.05)$. There was also a difference between the ptP+E- and ftP+E- groups $(t=4.1855, \mathrm{P}<0.05)$, but between neither the ptP-E- and ftP-E- groups $(t=0.5458, \mathrm{P}$ $>0.05)$, nor the ptP-E+ and ftP-E+ groups $(t=0.0843, P>0.05)$.

Regarding day 4 serum sTREM-1 levels (Fig. 2b), there were differences between the ptP+E- $(209.85 \pm 102.64 \mathrm{pg} / \mathrm{ml})$ and ptP-E- (75.50 $\pm 27.93 \mathrm{pg} / \mathrm{ml}) \mathrm{groups}(t$ $=5.4276, \mathrm{P}<0.05)$, between the ptP+E- and ptP-E+ $(487.24 \pm 305.65 \mathrm{pg} / \mathrm{ml})$ groups $(t=4.4207, \mathrm{P}<0.05)$, as well as between the ptP-E- and ptP-E+ groups $(t=$ $5.8549, \mathrm{P}<0.05)$. There were differences between the ftP+E- $(480.58 \pm 180.83 \mathrm{pg} / \mathrm{ml})$ and ftP-E- $(67.75 \pm 20.47 \mathrm{pg} / \mathrm{ml}) \mathrm{groups}(t=5.8906, \mathrm{P}<0.05)$, as well as between the ftP-E- and ftP-E+ $(623.69 \pm 167.12 \mathrm{pg} / \mathrm{ml})$ groups $(t=10.6367, \mathrm{P}<0.05)$, but not between the ftP+E- and ftP-E+groups $(t=1.6963, \mathrm{P}>0.05)$. There was also a difference between the ptP+E- and ftP+E- groups $(t=6.8963, \mathrm{P}<0.05)$, but between neither the ptP-E- and ftP-E- groups $(t=0.7749$, $\mathrm{P}>0.05)$, nor the ptP-E+ and ftP-E+ groups $(t=0.9721, \mathrm{P}>0.05)$.

Upon comparing day 4 BAL-fluid and serum sTREM-1 levels, there were differences within each group (group ptP+E-: $t=8.4948$, $\mathrm{P}<0.05$; group ptP-E-: $t=$ 3.0084, $\mathrm{P}<0.05$; group ptP-E+: $t=2.9537, \mathrm{P}<0.05$; group ftP+E-: $\mathrm{t}=3.9289, \mathrm{P}<0.05$; group ftP-E-: $\mathrm{t}=3.1141, \mathrm{P}<0.05$; and group ftP-E+: $\mathrm{t}=6.9060, \mathrm{P}<0.05$ ).

With respect to day 4 white blood cell count (Fig. 2c), there were differences between the ptP+E- $\left(11,358.46 \pm 4,704.71 / \mathrm{mm}^{3}\right)$ and ptP-E- $(7,728.83 \pm 1,818.86$ $\left./ \mathrm{mm}^{3}\right)$ groups $(t=4.7774, \mathrm{P}<0.05)$, between the ptP+E- and ptP-E $+\left(17,867.51 \pm 1,340.04 / \mathrm{mm}^{3}\right)$ groups $(t=6.9304, \mathrm{P}<0.05)$, as well as between the ptP-E- and ptP-E+ groups $(t=9.8140, \mathrm{P}<0.05)$. There were differences between the $\mathrm{ftP}+\mathrm{E}-\left(17,374.20 \pm 1,361.47 / \mathrm{mm}^{3}\right)$ and ftP-E- $\left(6,493.33 \pm 733.33 / \mathrm{mm}^{3}\right) \mathrm{groups}(t=$ $29.4420, \mathrm{P}<0.05)$, as well as between the ftP-E- and ftP-E+ $\left(17,658.22 \pm 1,849.32 / \mathrm{mm}^{3}\right)$ groups $(t=23.3148, \mathrm{P}<0.05)$, but not between groups ftP+E- and ftP-E+ 
$(t=0.6450, \mathrm{P}>0.05)$. There were also differences between groups ptP+E- and ftP+E- $(t=5.3034, \mathrm{P}<0.05)$, as well as between groups ptP-E- and ftP-E- $(t=$ $2.5348, \mathrm{P}<0.05)$, but not between groups ptP-E+ and ftP-E+ $(t=0.2363, \mathrm{P}>0.05)$.

With reference to day 4 serum C-reactive protein levels (Fig. $2 \mathrm{~d})$, there were differences between the ptP+E- $(6.87 \pm 2.61 \mathrm{ng} / \mathrm{ml}) \mathrm{and} \mathrm{ptP-E-}(0.65 \pm 0.32 \mathrm{ng} / \mathrm{ml})$ groups $(t=10.0254, \mathrm{P}<0.05)$, between the $\mathrm{ptP}+\mathrm{E}-$ and $\mathrm{ptP}-\mathrm{E}+(3.61 \pm 1.49 \mathrm{ng} / \mathrm{ml})$ groups $(t=3.1819, \mathrm{P}<0.05)$, as well as between groups ptP-E- and ptP-E+ $(t=$ $6.1642, \mathrm{P}<0.05)$. There were differences between the ftP+E- $(8.92 \pm 2.14 \mathrm{ng} / \mathrm{ml})$ and ftP-E- $(1.52 \pm 1.47 \mathrm{ng} / \mathrm{ml}) \mathrm{groups}(t=7.1073, \mathrm{P}<0.05)$, between the ftP+Eand ftP-E+ $(5.28 \pm 3.98 \mathrm{ng} / \mathrm{ml})$ groups $(\mathrm{t}=2.8448, \mathrm{P}<0.05)$, as well as between groups ftP-E- and ftP-E+ $(t=2.7430, \mathrm{P}<0.05)$. There was also a difference between groups ptP+E- and ftP+E- $(t=2.8028, \mathrm{P}<0.05)$, as well as between groups ptP-E- and ftP-E- $(t=2.4435, \mathrm{P}<0.05)$, but not between groups ptP-E+ and $\mathrm{ftP}-\mathrm{E}+(t=1.0350, \mathrm{P}>0.05)$.

Concerning day 4 serum procalcitonin levels (Fig. $2 \mathrm{e})$, there was a difference between the ptP+E- $(4.54 \pm 1.36 \mathrm{ng} / \mathrm{ml})$ and ptP-E- $(0.15 \pm 0.19 \mathrm{ng} / \mathrm{ml}) \mathrm{groups}(t=$ $19.4827, \mathrm{P}<0.05)$, as well as between the ptP-E- and ptP-E+ $(5.38 \pm 0.94 \mathrm{ng} / \mathrm{ml})$ groups $(t=15.1137, \mathrm{P}<0.05)$, but not between groups ptP+E- and ptP-E $(t=$ $2.6115, \mathrm{P}>0.05)$. There were differences between the $\mathrm{ftP}+\mathrm{E}-(4.86 \pm 1.29 \mathrm{ng} / \mathrm{ml})$ and ftP-E- $(0.39 \pm 0.45 \mathrm{ng} / \mathrm{ml}) \mathrm{groups}(t=9.5044, \mathrm{P}<0.05)$, between the ftP+Eand $\mathrm{ftP}-\mathrm{E}+(9.23 \pm 3.32 \mathrm{ng} / \mathrm{ml})$ groups $(t=7.7982, \mathrm{P}<0.05)$, as well as between groups ftP-E- and ftP-E+ $(t=14.5059, \mathrm{P}<0.05)$. There was also a difference between groups ptP+E- and ftP+E- $(t=1.9879, \mathrm{P}<0.05)$, as well as between groups ptP-E- and ftP-E- $(t=0.8090, \mathrm{P}<0.05)$, but not between groups ptP-E+ and $\mathrm{ftP}-\mathrm{E}+(t=2.9529, \mathrm{P}>0.05)$.

Bacterial culture results from serum and BAL fluid indicated the presence of various bacteria, as summarized in Table 1.

\subsection{Receiver operating characteristic analysis of indicators for pneumonia}

Fig. 3 illustrates the ROC analysis performed to determine the diagnostic value of indicators in groups ptP+E- and ftP+E-. Table 2 summarizes the results in terms of area under the curve (AUC), cutoff value, sensitivity, and specificity. For both groups, the AUCs of BAL-fluid sTREM-1, serum sTREM-1, and serum Creactive protein were statistically significant $(P<0.05)$. The AUCs of serum procalcitonin and BAL-fluid/serum sTREM- 1 were only statistically significant for group ptP+E- $(P<0.05)$. The AUC of white blood cell count was not statistically significant for either group $(P>0.05)$.

We constructed multivariate logistic regression models incorporating different pairs of markers. Using prediction probability as diagnostic indicator, we determined diagnostic cutoff values from the ROC curve. The AUCs of the two-marker models were all larger than that of any single marker model. The optimal combination was BAL-fluid sTREM-1 and serum C-reactive protein concentration, for which AUC ( $95 \%$ confidence interval [CI]), sensitivity, and specificity was 0.968 (0.909-0.999), 98.9\%, and 72.7\%, respectively, in group ptP+E-, and $0.926(0.918-1.000), 95.6 \%$, and $92.4 \%$, respectively, in group ftP+E- .

\subsection{Repeated measures ANOVA of indicators for ventilator-associated pneumonia}

In the ptP+E- and ftP+E- groups, $19 / 35$ and 11/17 neonates, respectively, recovered. All indicators were more favorable at the third and fourth time points in neonates who recovered than in those who did not, in each group (all $\mathrm{P}<0.05$; Table 3 ). We observed no differences at any time point for serum or BAL-fluid sTREM-1 concentrations between the ptP+E- and ftP+E- groups (all $\mathrm{P}>0.05$ ), and none of the values changed over time in ptP+E- or $\mathrm{ftP}+\mathrm{E}-$ neonates who did not recover (all $\mathrm{P}>0.05)$.

\section{Discussion}

STREM-1, a member of the immunoglobulin superfamily, is a soluble TREM-1 that is upregulated when neutrophils are exposed to bacteria, but not during noninfectious inflammatory diseases, which suggests that sTREM-1 may be a specific marker for infectious diseases [10-12]. Previous research has demonstrated that sTREM-1 yielded a high sensitivity (>95\%) and specificity (> 85\%) in systemic inflammatory response syndrome patients [13, 14], and may be more useful than C-reactive protein and procalcitonin with regard to sepsis diagnosis in adult and pediatric patients [15, 16]. sTREM-1 can be measured directly in human body fluids, including serum, pleural effusion, sputum, and urine, during infections [14, 17]. The concentration of sTREM-1 has been demonstrated to rise in the BAL fluid of VAP patients [6, 18-20], including a pediatric research of VAP patients after cardiac surgery, but none about neonatal VAP [21].

In this study, we investigated the usefulness of sTREM-1 concentration in serum and BAL fluid for the diagnosis of NVAP. We assessed preterm and full-term neonates separately, due to their different physiological characteristics. Among both of these groups, the BAL-fluid sTREM-1 concentration was higher, on average, in those diagnosed with NVAP without extrapulmonary infection than in those not diagnosed with NVAP, irrespective of the presence of extrapulmonary infection. Among those diagnosed with NVAP without extrapulmonary infection, BAL-fluid sTREM-1 concentrations were higher, on average, in full-term than in preterm neonates, which may indicate a stronger ability to express sTREM- 1 by the immune system of the former.

Among both preterm and full-term neonates, the mean serum STREM-1 concentration was higher in both those not diagnosed with NVAP but indeed with extrapulmonary infection, and in those diagnosed with NVAP and no extrapulmonary infection, than in those not diagnosed with NVAP or extrapulmonary infection. However, only among full-term neonates was the mean serum sTREM-1 concentration higher in those not diagnosed with NVAP but indeed with extrapulmonary infection, than in those diagnosed with NVAP and no extrapulmonary infection. As with BAL-fluid sTREM-1, among those diagnosed with NVAP without extrapulmonary infection, serum STREM-1 concentrations were higher, on average, in full-term than in preterm neonates.

Among neonates diagnosed with NVAP without extrapulmonary infection, the mean concentration of BAL-fluid sTREM-1 was higher than that of serum STREM-1; however, this was reversed among those without NVAP, but with extrapulmonary infection. This can be understood because of the difference in infection sites. In neonates not diagnosed with NVAP or extrapulmonary infection, the BAL-fluid sTREM-1 concentration was higher, on average, than that of serum STREM-1; however, the relatively low concentration of BAL-fluid sTREM-1 in NVAP-negative cases may indicate that the application of a mechanical 
ventilator reduces the secretion of BAL-fluid sTREM-1. As we did not compare these concentrations to non-ventilated neonates, however, further research is required to identify such an influence.

Mean serum C-reactive protein and procalcitonin concentrations were also higher in infection cases; white blood cell count, however, was decreased in some infection cases. Similar pathogens were present in the BAL-fluid of preterm and full-term neonates with NVAP; no pathogens were detected in BAL fluid of neonates without NVAP.

We identified BAL fluid sTREM-1 concentration as an indicator of NVAP, with an AUC of $0.986(95 \% \mathrm{Cl}, 0.920-1.000)$ and a cutoff value of $228.0 \mathrm{pg} / \mathrm{ml}$ (sensitivity $=94.3 \%$, specificity $=96.0 \%)$ in preterm neonates, and an AUC value of $0.938(95 \% \mathrm{Cl}, 0.937-1.000)$ and a cutoff value of $245.5 \mathrm{pg} / \mathrm{ml}$ (sensitivity $=100.0 \%$, specificity $=93.7 \%$ ) in full-term neonates. These results are similar to those of a previous study [22], and demonstrated its potential utility for NVAP diagnosis. We also observed an increased mean serum sTREM-1 concentration in NVAP cases; however, its AUC, sensitivity, and specificity were lower than those of mean BAL-fluid STREM-1 concentration. One study revealed no statistically significant difference between BAL-fluid and serum sTREM-1 concentrations in VAP patients [22], whereas others revealed a higher concentration of BAL-fluid sTREM-1 than that in the serum [23, 24]. Therefore, we also analyzed the ratio of BAL-fluid to serum sTREM-1 concentration for its effectiveness as an indicator of NVAP. This ratio had lower AUC and specificity values (as low as $37.5 \%$ in full-term neonates), on average, than that of BAL-fluid sTREM concentration. This suggests that the BAL-fluid/serum sTREM-1 ratio is not an effective indicator of NVAP. Upon analysis of the other indicators, we discovered that serum C-reactive protein had an $\mathrm{AUC}$ of 0.947 ( $95 \% \mathrm{Cl}, 0.896-0.998)$ and a cutoff value of $2.88 \mathrm{ng} / \mathrm{ml}$ (sensitivity $=91.4 \%$, specificity $=84.0 \%)$ in preterm neonates, and an AUC value of $0.915(95 \% \mathrm{Cl}, 0.903-1.000)$ and a cutoff value of $6.25 \mathrm{ng} / \mathrm{ml}$ (sensitivity $=94.1 \%$, specificity $=87.5 \%$ ) in full-term neonates. Therefore, it may also be an effective indicator of NVAP. However, analysis of white blood cell count and serum procalcitonin concentration exhibited AUCs below 0.7 in each group. Upon multivariate logistic regression analysis, the optimal model for predicting NVAP was that incorporating both BAL-fluid sTREM-1 and serum C-reactive protein concentration. This combination was a better predictor of NVAP than any single indicator.

All five indicators tested were present at lower levels on days 8 and 10 of ventilation in neonates who ultimately recovered, than in those who did not, and none of these markers improved notably from day 4 to day 10 in patients who did not recover.

The major limitation of this study was the lack of baseline measurements for the indicators analyzed, i.e., measured before ventilator use. Furthermore, there is no data in terms of the standard range of BAL-fluid and serum sTREM-1 concentrations in healthy preterm and full-term neonates. Finally, there are no gold standard criteria for the diagnosis of NVAP.

\section{Conclusion}

We have demonstrated that the BAL-fluid STREM-1 and serum C-reactive protein concentrations may be useful for the diagnosis of NVAP in both preterm and full-term neonates. Further research is required to determine the generalizability of these results.

\section{Declarations}

\section{Ethics approval and consent to participate}

The RCT was approved by the Ethics Review Committee of The First People's Hospital of Yongkang (number: ykyy201803) and was in accordance with the 1964 Helsinki declaration and its later amendments or comparable ethical standards. Written informed consent was obtained from a parent or guardian for participants under 16 years old in the study.

\section{Consent for publication}

Not applicable.

\section{Availability of data and material}

The datasets used and/or analysed during the current study are available from the corresponding author on reasonable request.

\section{Competing interests}

The authors declare that they have no conflict of interest.

\section{Funding}

This work was supported by Jinhua Municipal Science and Technology Bureau (CN, no. 2018-4-151).

\section{Authors' contributions}

JZ and LTH conceived and designed the study; LTH, JZ, YH and YCW performed the test; JZ, HHL and JQZ analysed the data; and JZ wrote the paper. All authors have read and approved the manuscript.

\section{Acknowledgments}

The authors would like to thank the participants, who made this study possible. 


\section{References}

1. Cernada M, Brugada M, Golombek S, Vento M. Ventilator-associated pneumonia in neonatal patients: an update. 2014;105:98-107.

2. Rocha G, Soares P, Gonçalves A, Silva Al, Almeida D, Figueiredo S, Pissarra S, Costa S, Soares H, Flôr-de-Lima F, Guimarães H. Respiratory care for the ventilated neonate. Can Respir J. 2018;7472964.

3. Fanaroff AA, Stoll BJ, Wright LL, Carlo WA, Ehrenkranz RA, Stark AR, Bauer CR, Donovan EF, Korones SB, Laptook AR, Lemons JA, Oh W, Papile LA, Shankaran S, Stevenson DK, Tyson JE, Poole WK, NICHD Neonatal Research Network. Trends in neonatal morbidity and mortality for very low birthweight infants. Am J Obstet Gynecol. 2007;196:147.e141-147.e148.

4. Hunter JD. Ventilator associated pneumonia. Postgrad Med J. 2006;82:172-178.

5. Kohbodi GA, Rajasurya V, Noor A. Pneumonia, Ventilator-associated. In: StatPearls [Internet]. Treasure Island (FL): StatPearls Publishing. 2020. https://www.ncbi.nlm.nih.gov/books/NBK507711/. Accessed 11 Jun 2020.

6. Oudhuis GJ, Beuving J, Bergmans D, Stobberingh EE, ten Velde G, Linssen CF, Verbon A. Soluble Triggering Receptor Expressed on Myeloid cells-1 in bronchoalveolar lavage fluid is not predictive for ventilator-associated pneumonia. Intensive Care Med. 2009;35:1265-1270.

7. Palazzo SJ, Simpson TA, Simmons JM, Schnapp LM. Soluble triggering receptor expressed on myeloid cells-1 (sTREM-1) as a diagnostic marker of ventilator-associated pneumonia. Respir Care. 2012;57:2052-2058.

8. Pneumonia (Ventilator-associated [VAP] and non-ventilator-associated Pneumonia [PNEU]) Event. Device Associated Module. January 2016.

9. Fabiano A, Gazzolo D, Zimmermann LJI, Gavilanes AWD, Paolillo P, Fanos V, Caboni P, Barberini L, Noto A, Atzori L. Metabolomic analysis of bronchoalveolar lavage fluid in preterm infants complicated by respiratory distress syndrome: preliminary results. J Matern Fetal Neonatal Med. 2011;24(Suppl 2):55-58.

10. Bouchon A, Dietrich J, Colonna M. Cutting edge: inflammatory responses can be triggered by TREM-1, a novel receptor expressed on neutrophils and monocytes. J Immunol. 2000;164:4991-4995.

11. Jedynak M, Siemiatkowski A, Milewski R, Mroczko B, Szmitkowski M. Diagnostic effectiveness of soluble triggering receptor expressed on myeloid cells-1 in sepsis, severe sepsis and septic shock. Arch Med Sci. 2019;15:713-721.

12. Pontrelli G, De Crescenzo F, Buzzetti R, Calò Carducci F, Jenkner A, Amodio D, De Luca M, Chiurchiù S, Davies EH, Simonetti A, Ferretti E, Della Corte M, Gramatica L, Livadiotti S, Rossi P. Diagnostic value of soluble triggering receptor expressed on myeloid cells in paediatric sepsis: a systematic review. Ital J Pediatr. 2016;42:44.

13. Lemarié J, Gibot S. Soluble triggering receptor expressed on myeloid cells-1: diagnosis or prognosis? Crit Care Clin. 2020;36:41-54.

14. Patoulias D, Kalogirou MS, Patoulias I. Triggering Receptor Expressed on Myeloid Cells-1 (TREM-1) and its soluble in the plasma form (sTREM-1) as a diagnostic biomarker in neonatal sepsis. Folia Med Cracov. 2018;58(2):15-19.

15. Cao C, Gu J, Zhang J. Soluble triggering receptor expressed on myeloid cell-1 (sTREM-1): a potential biomarker for the diagnosis of infectious diseases. Front Med. 2017;11:169-177.

16. Alkan Ozdemir S, Ozer EA, Ilhan O, Sutcuoglu S, Tatlı M. Diagnostic value of urine soluble triggering receptor expressed on myeloid cells (sTREM-1) for late-onset neonatal sepsis in infected preterm neonates. J Int Med Res. 2018;46:1606-1616.

17. Determann RM, Schultz MJ, Geerlings SE. Soluble triggering receptor expressed on myeloid cells-1 is not a sufficient biological marker for infection of the urinary tract. J Infect. 2007;54:e249-e250.

18. Anand NJ, Zuick S, Klesney-Tait J, Kollef MH. Diagnostic implications of soluble triggering receptor expressed on myeloid cells-1 in BAL fluid of patients with pulmonary infiltrates in the ICU. Chest. 2009;135:641-647.

19. Kollef MH, Anand N, Zuick S, Klesney-Tait J. Soluble triggering receptor expressed on myeloid cells 1 and the diagnosis of ventilator-associated pneumonia: response. Chest. 2009;136:320.

20. Gibot S. Soluble triggering receptor expressed on myeloid cells-1 and diagnosis of ventilator-associated pneumonia. Intensive Care Med. 2009;35:1644, author reply:1645-1646.

21. Matsuno AK, Carlotti APCP. Role of soluble triggering receptor expressed on myeloid cells- 1 for diagnosing ventilator-associated pneumonia after cardiac surgery: an observational study. BMC Cardiovasc Disord. 2013;13:107.

22. Gibot S, Cravoisy A, Dupays R, Barraud D, Nace L, Levy B, Bollaert PE. Combined measurement of procalcitonin and soluble TREM-1 in the diagnosis of nosocomial sepsis. Scand J Infect Dis. 2007;39:604-608.

23. El Solh AA, Akinnusi ME, Peter M, Berim I, Schultz MJ, Pineda L. Triggering receptors expressed on myeloid cells in pulmonary aspiration syndromes. Intensive Care Med. 2008;34:1012-1019.

24. Gibot S, Cravoisy A, Levy B, Bene MC, Faure G, Bollaert PE. Soluble triggering receptor expressed on myeloid cells and the diagnosis of pneumonia. N Engl J Med. 2004;350:451-458.

\section{Tables}

Table 1 Bacterial culture results of serum and BAL fluid in each group 


\begin{tabular}{|lll|}
\hline Group* & Bacteria from blood & Bacteria from BAL fluid \\
\hline ptP+E- & S. epidermidis (1) & K. pneumoniae (6), P. aeruginosa (4), A. baumannii (3) E. coli (3), C. albicans (1) \\
\hline ptP-E- & None & None \\
\hline ptP-E+ & A. baumannii (1) E. coli (3) & None \\
\hline ftP+E- & C. albicans (1) & K. pneumoniae (4), P. aeruginosa (2), A. baumannii (1), E. coli (1) \\
\hline ftP-E- & S. epidermidis (1) & None \\
ftP-E+ & A. baumannii (1), E. coli (2), P. aeruginosa (1) & None \\
\hline
\end{tabular}

*Groups are based on three categories: preterm (pt) or full-term (ft); NVAP (P+) or non-NVAP (P-); and extrapulmonary infection present (E+) or absent (E-). ${ }^{\dagger}$ Numbers in parentheses indicate the number of neonates testing positive for the bacterial species. BAL, bronchoalveolar lavage; $S$. epidermidis, Staphylococcus epidermidis; A. baumannii, Acinetobacter baumannii, E. coli, Escherichia coli; C. albicans, Candida albicans, P. aeruginosa, Pseudomonas aeruginosa; K. pneumoniae, Klebsiella pneumoniae; NVAP, neonatal ventilator-associated pneumonia.

Table 2 ROC analysis of indicators in groups ptP+E- and ftP+E-

\begin{tabular}{|c|c|c|c|c|c|c|c|c|c|c|c|}
\hline Indicator & AUC & $\begin{array}{l}95 \% \\
\mathrm{Cl}\end{array}$ & Cutoff value & Sensitivity & Specificity & Indicator & AUC & $\begin{array}{l}95 \% \\
\mathrm{Cl}\end{array}$ & Cutoff value & Sensitivity & $\mathrm{SF}$ \\
\hline $\begin{array}{l}\text { BAL-fluid } \\
\text { sTREM-1 }\end{array}$ & $0.986^{*}$ & $\begin{array}{l}0.920 \\
- \\
1.000\end{array}$ & $228.0 \mathrm{pg} / \mathrm{ml}$ & $94.3 \%$ & $96.0 \%$ & $\begin{array}{l}\text { BAL-fluid } \\
\text { sTREM-1 }\end{array}$ & $0.938^{*}$ & $\begin{array}{l}0.937 \\
- \\
1.000\end{array}$ & $245.5 \mathrm{pg} / \mathrm{ml}$ & $100.0 \%$ & $9 i$ \\
\hline $\begin{array}{l}\text { Serum } \\
\text { sTREM-1 }\end{array}$ & $0.689 *$ & $\begin{array}{l}0.535 \\
- \\
0.843\end{array}$ & $105.5 \mathrm{pg} / \mathrm{ml}$ & $82.9 \%$ & $60.0 \%$ & $\begin{array}{l}\text { Serum } \\
\text { sTREM-1 }\end{array}$ & $0.688^{\star}$ & $\begin{array}{l}0.474 \\
- \\
0.901\end{array}$ & $129.0 \mathrm{pg} / \mathrm{ml}$ & $94.1 \%$ & $6:$ \\
\hline $\begin{array}{l}\text { BAL- } \\
\text { fluid/serum } \\
\text { sTREM-1 }\end{array}$ & 0.720 & $\begin{array}{l}0.650 \\
- \\
0.890\end{array}$ & 1.4926 & $94.3 \%$ & $68.0 \%$ & $\begin{array}{l}\text { BAL- } \\
\text { fluid/serum } \\
\text { sTREM-1 }\end{array}$ & 0.669 & $\begin{array}{l}0.481 \\
- \\
0.857\end{array}$ & 1.2591 & $100.0 \%$ & 3 \\
\hline $\begin{array}{l}\text { White blood } \\
\text { cells }\end{array}$ & 0.521 & $\begin{array}{l}0.361 \\
- \\
0.681\end{array}$ & $10250.00 / \mathrm{mm}^{3}$ & $62.9 \%$ & $68.0 \%$ & $\begin{array}{l}\text { White blood } \\
\text { cells }\end{array}$ & 0.669 & $\begin{array}{l}0.450 \\
- \\
0.888\end{array}$ & $11700.00 / \mathrm{mm}^{3}$ & $100.0 \%$ & $6:$ \\
\hline $\begin{array}{l}\text { Serum C- } \\
\text { reactive } \\
\text { protein }\end{array}$ & $0.947^{*}$ & $\begin{array}{l}0.896 \\
- \\
0.998\end{array}$ & $2.88 \mathrm{ng} / \mathrm{ml}$ & $91.4 \%$ & $84.0 \%$ & $\begin{array}{l}\text { Serum C- } \\
\text { reactive } \\
\text { protein }\end{array}$ & $0.915^{\star}$ & $\begin{array}{l}0.903 \\
- \\
1.000\end{array}$ & $6.25 \mathrm{ng} / \mathrm{ml}$ & $94.1 \%$ & $8:$ \\
\hline $\begin{array}{l}\text { Serum } \\
\text { procalcitonin }\end{array}$ & $0.762^{\star}$ & $\begin{array}{l}0.608 \\
- \\
0.917\end{array}$ & $1.24 \mathrm{ng} / \mathrm{ml}$ & $100.0 \%$ & $72.0 \%$ & $\begin{array}{l}\text { Serum } \\
\text { procalcitonin }\end{array}$ & 0.651 & $\begin{array}{l}0.424 \\
- \\
0.877\end{array}$ & $2.28 \mathrm{ng} / \mathrm{ml}$ & $100.0 \%$ & $6:$ \\
\hline Group ptP+E- ${ }^{\dagger}$ & & & & & & Group ftP+E- ${ }^{\dagger}$ & & & & & \\
\hline
\end{tabular}

${ }^{*} \mathrm{P}<0.05 .{ }^{\dagger}$ Groups are based on three categories: preterm (pt) or full-term ( $\mathrm{ft}$ ); neonatal ventilator-associated pneumonia (P+); and extrapulmonary infection absent (E-). ROC, receiver operating characteristic; AUC, area under the curve; $\mathrm{Cl}$, confidence interval; BAL, bronchoalveolar fluid; sTREM, soluble triggering receptor expressed on myeloid cells-1.

\section{Figures}

\begin{tabular}{l|l|l|}
$\begin{array}{l}\text { Analyzed } \\
(\mathrm{n}=17)\end{array}$ & $\begin{array}{l}\text { Interruption of treatment } \\
(\mathrm{n}=1)\end{array}$ \\
$\begin{array}{l}\text { Interruption of treatment } \\
(\mathrm{n}=0)\end{array}$ & $\begin{array}{l}\mathrm{ftP}+\mathrm{E}- \\
\mathrm{n}=9 \mathrm{n})\end{array}$ \\
$\mathrm{ftP}+\mathrm{E}+$ \\
$(\mathrm{n}=1)$
\end{tabular}

\begin{tabular}{|l|l|l|}
\hline $\begin{array}{l}\mathrm{ptP}+\mathrm{E}- \\
(\mathrm{n}=42)\end{array}$ \\
\hline $\begin{array}{l}\mathrm{ptP}+\mathrm{E}+ \\
(\mathrm{n}=1)\end{array}$
\end{tabular}
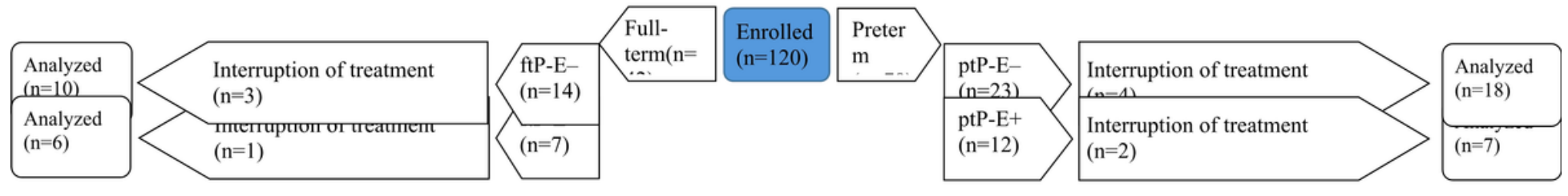

Figure 1 
A flow diagram of the trial Neonates were divided into eight groups based on three categories: preterm (pt) or full-term (ft); NVAP (P+) or non-NVAP (P-); and extrapulmonary infection present (E+) or absent (E-). NVAP, neonatal ventilator-associated pneumonia.
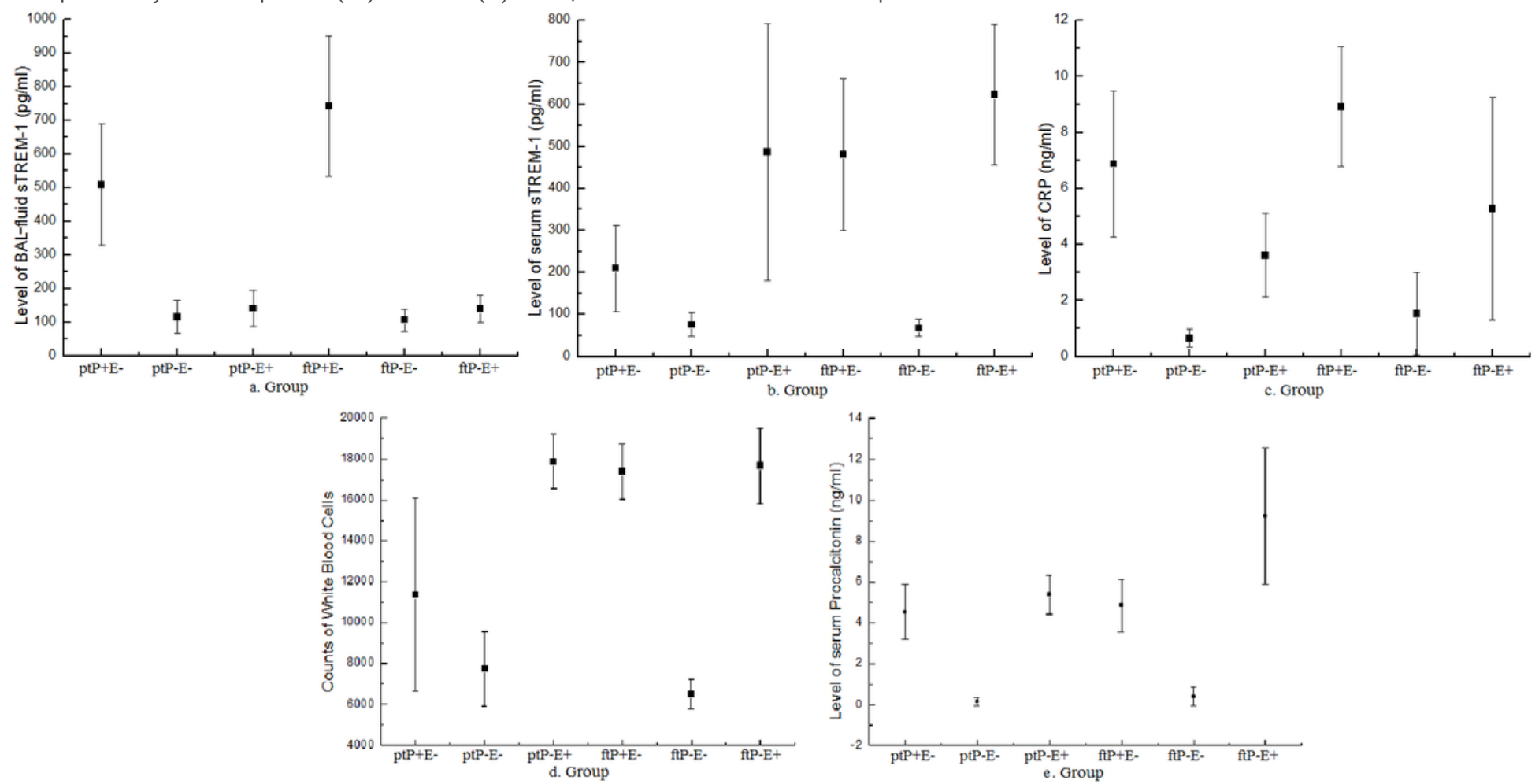

Figure 2

Values of indicators on the fourth day on the mechanical ventilator Dots represent mean values and error bars represent the standard deviation. Groups are based on three categories: preterm (pt) or full-term ( $f t)$; NVAP ( $P+$ ) or non-NVAP (P-); and extrapulmonary infection present ( $E+$ ) or absent (E-). BAL, bronchoalveolar lavage; sTREM-1, soluble triggering receptor expressed on myeloid cells-1; CRP, C-reactive protein; NVAP, neonatal ventilator-associated pneumonia.

a. ROC Curve of group ptP+E-

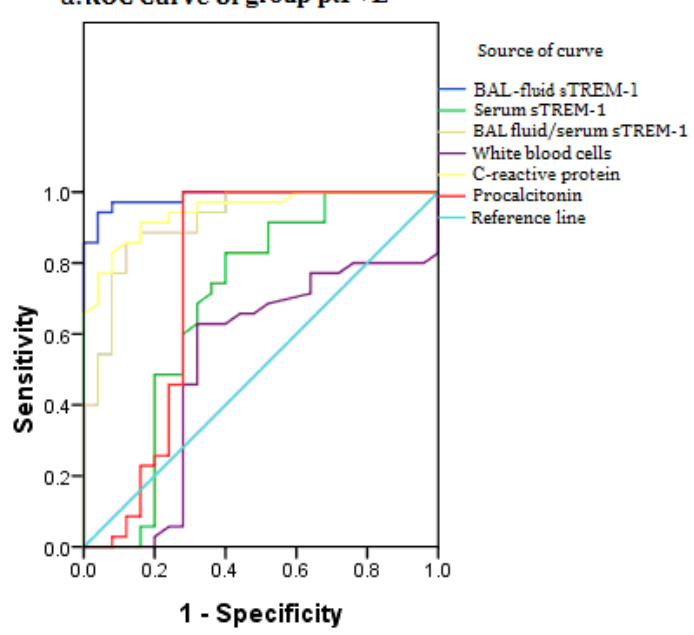

\section{b. ROC Curve of group $\mathrm{ftP}+\mathrm{E}$ -}

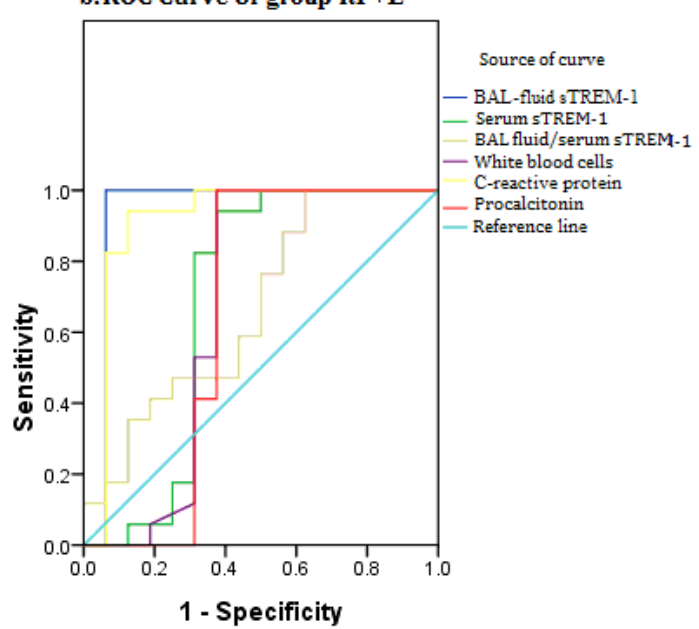

Figure 3

ROC curve of groups ptP+E- and ftP+E- Groups are based on three categories: preterm (pt) or full-term (ft); NVAP (P+); and extrapulmonary infection absent (E-). ROC, receiver operating characteristic; BAL, bronchoalveolar lavage; STREM-1, soluble triggering receptor expressed on myeloid cells-1; NVAP, neonatal ventilator-associated pneumonia.

\section{Supplementary Files}

This is a list of supplementary files associated with this preprint. Click to download.

- SupplementaryFile1Checklist.doc 